\title{
Effect of fertilization and variety on digestibility of phosphorus from plant feedstuffs in pigs
}

\author{
M. Hovenjürgen ${ }^{1}$, M. Rodehutscord ${ }^{2}$ and E. Pfeffer ${ }^{1}$ \\ ${ }^{1}$ University of Bonn, Department of Animal Nutrition \\ Endenicher Allee 15, D-53115 Bonn, Germany \\ ${ }^{2}$ University of Halle-Wittenberg, Department of Nutritional Sciences \\ D-06099 Halle, Germany
}

(Received 11 August 2002; accepted 20 December 2002)

\begin{abstract}
Three experiments were performed to determine the digestibility of phosphorus in plant feedstuffs for pigs. Pigs initially weighing $11 \mathrm{~kg}$ were kept in metabolism crates and fed twice daily at about 2 to 2.5 -fold metabolizable energy requirement for maintenance. A semi-purified diet low in phosphorus and without intrinsic phytase activity was fed either alone or after blending into test diets containing $60 \%$ of barley or wheat or $40 \%$ of field bean or rye. Mixtures were calculated to contain not more than $2 \mathrm{~g}$ digestible $\mathrm{P} / \mathrm{kg}$ DM and between 5.0 to $6.0 \mathrm{~g} \mathrm{Ca} / \mathrm{kg}$ DM. Faeces and urine were quantitatively collected for 7 days after 7 days of adaptation. Phosphorus digestibility for ingredients under test was calculated from differences of results on test and basal diet. Digestibility of phosphorus in three different batches of rye was $70 \%$ on average. In two batches of field bean the digestibility coefficient was $36 \%$. Phosphorus digestibility in 12 batches of wheat ranged from 43 to $59 \%$, with a mean of $56 \%$, in six batches of barley the digestibility coefficient ranged from 42 to $52 \%$ with a mean of $46 \%$. There was no effect of fertilization with nitrogen or phosphorus on the digestibility of phosphorus in wheat, rye or barley. A variety effect on digestibility was indicated for barley and wheat. No clear relation was found between $P$ digestibility on the one hand and portion of phytate-bound $\mathrm{P}$ or activity of intrinsic phytase activity on the other hand.
\end{abstract}

KEYWORDS: phosphorus, phytase, phytate, P digestibility, pigs

\section{INTRODUCTION}

Like in Denmark and the Netherlands, in Germany the phosphorus (P) supply to pigs is calculated on the basis of "digestible P" (dP), according to the recommendation of the Society of Nutrition Physiology (GfE, 1997). For calculating 
mixed diets, values for digestibility of $\mathrm{P}$ in individual ingredients are needed. $\mathrm{P}$ digestibility in plant feedstuffs varies in a wide range, even for different batches of one species (Rodehutscord et al., 1996). As part of the phosphorus of plant origin is bound as phytate $\mathrm{P}$ (Eeckhout and De Paepe, 1994), which is poorly available to the pig, the portion of phytate-bound $\mathrm{P}$, as well as the activity of intrinsic phytase, may affect the $\mathrm{P}$ digestibility. Only few data on $\mathrm{P}$ digestibility of plant feedstuffs have been published, and factors affecting digestibility within one feedstuff apart from the above mentioned have hardly been investigated. This study aimed to determine effects of fertilization with $\mathrm{N}$ and $\mathrm{P}$ and variety on the digestibility of phosphorus in plant feedstuffs for pigs. In addition, this study attempts to determine whether P digestibility is related to the portion of phytate-bound $\mathrm{P}$ or activity of intrinsic phytase.

\section{MATERIAL AND METHODS}

Diets

So far, no in-vitro-method has been developed for estimating P digestibility and, therefore, studies with pigs are required. Recommendations for these procedures are described by GfE (1994). Three balance trials were carried out, each experiment comprised two 4 x 4 Latin squares run concurrently. In the first experiment four batches of spring wheat and three batches of spring rye were tested. The batches of each grain differed only in fertilization with $\mathrm{P}$ and animal dung for many years, they came from a long-term fertilization trial. In experiment 2 , the digestibility of phosphorus of four batches of winter wheat and four batches of winter barley was determined. The batches of each grain differed only in fertilization with $\mathrm{P}$ and nitrogen (fertilization with $44 \mathrm{~kg}$ P/ha or without $\mathrm{P}$; fertilization with $\mathrm{N}$ at different levels: 180 or $90 \mathrm{~kg} \mathrm{~N} / \mathrm{ha}$ for wheat and 150 or $75 \mathrm{~kg} \mathrm{~N} / \mathrm{ha}$ for barley). In experiment 3, the digestibility of phosphorus was determined for two varieties of field bean, two varieties of winter barley and four varieties of winter wheat. Because the concentration of $\mathrm{P}$ in the test components was too high to feed them alone, they had to be blended into a semi-purified basal diet (BD) with a very low phosphorus concentration and without intrinsic phytase activity. This BD was fed either alone (one of the diets in trial 1) or after blending into test diets containing $60 \%$ of barley or wheat or $40 \%$ of field bean or rye. Level of inclusion of field bean and rye was lower than for wheat and barley to prevent reduced feed intake for these test diets. Mixtures were calculated to contain not more than $2 \mathrm{~g} \mathrm{dP} / \mathrm{kg} \mathrm{DM}$ and between 5.0 to $6.0 \mathrm{~g} \mathrm{Ca} / \mathrm{kg} \mathrm{DM}$. Phosphorus digestibility for ingredients under test was calculated from differences of results on test and basal diet. The composition of the basal diet is given in Table 1 . The composition of the test diets is described 
in Table 2. Limestone was added to each test diet to maintain Ca concentrations comparable with those of the basal diet. Diets were not pelleted.

TABLE 1

Composition of the basal diet

\begin{tabular}{lc}
\hline Component & $\mathrm{g} \mathrm{kg}^{-1}$ \\
\hline Gelatinised potato starch & 540 \\
Dried sugar beet pulp & 180 \\
Potato protein & 110 \\
Dried egg white & 90 \\
Cellulose & 22 \\
Sugar & 20 \\
Soya bean oil & 17 \\
Vitamins and minerals ${ }^{1}$ & 10 \\
Limestone & 8 \\
NaCl & 1.0 \\
L-Lysin·HCl & 1.5 \\
L-Tryptophan & 0.5 \\
\hline
\end{tabular}

${ }^{1}$ for details of composition see Düngelhoef et al. (1994)

TABLE 2

Composition of test diets, $\mathrm{g} \cdot \mathrm{kg}^{-1}$

\begin{tabular}{|c|c|c|c|c|c|c|c|}
\hline \multirow{3}{*}{$\begin{array}{l}\text { Selection criteria } \\
\text { Type of grain }\end{array}$} & \multicolumn{4}{|c|}{ Fertilization } & \multicolumn{3}{|c|}{ Variety } \\
\hline & \multicolumn{2}{|c|}{ Spring } & \multicolumn{2}{|c|}{ Winter } & \multirow{2}{*}{$\begin{array}{l}\text { Field } \\
\text { bean }\end{array}$} & \multirow{2}{*}{$\begin{array}{l}\text { Winter } \\
\text { barley }\end{array}$} & \multirow{2}{*}{$\begin{array}{l}\text { Winter } \\
\text { wheat }\end{array}$} \\
\hline & rye & wheat & barley & wheat & & & \\
\hline Batches, $\mathrm{n}$ & 3 & 4 & 4 & 4 & 2 & 2 & 4 \\
\hline Basal diet, $\mathrm{g} \cdot \mathrm{kg}^{-1}$ & 595 & 392 & 393 & 393 & 595 & 392 & 392 \\
\hline Grain, $g \cdot \mathrm{kg}^{-1}$ & 400 & 600 & 600 & 600 & 400 & 600 & 600 \\
\hline Limestone, $\mathrm{g} \cdot \mathrm{kg}^{-1}$ & 5 & 8 & 7 & 7 & 5 & 8 & 8 \\
\hline
\end{tabular}

\section{Animals and feeding}

Castrated male pigs, initially weighing $11 \mathrm{~kg}$ were kept in metabolism crates and fed twice daily at about 2 to 2.5 -fold metabolizable energy requirement for maintenance.

Mean daily gain of body mass was about $255 \mathrm{~g}$ during the trials. The amounts of feed were kept constant during the individual periods of 14 days and were then adjusted to the increase in the pigs body mass at the beginning of each period when diets where switched between animals. Diets were fed twice daily at about 7.30 and $15.30 \mathrm{~h}$, moistened in deionised water directly before feeding and after each meal, deionised water was offered ad libitum for about $30 \mathrm{~min}$. In each period, after 7 days of adaptation, faeces and urine were collected quantitatively for 7 days. 


\section{Analyses and calculations}

Samples of feed, faeces and urine were dried, and ashed at $550^{\circ} \mathrm{C}$. The remaining ash was extracted with $6 \mathrm{~N} \mathrm{HCl}$. P was determined photometrically (Beckman, type D62, Munich, Germany) as orthophosphate from filtered ash solutions, using the vanado-molybdate method. The phytase activity of ingredients was measured using the method reported by Engelen et al. (1994). Determination of phytate P was carried out as detailed by Harland and Oberleas (1986). Proximate analysis of feeds and faeces was done according to the official methods in Germany (Naumann and Bassler, 1976). P digestibility (x, \%) of ingredients under test were calculated by difference from the experimental diets and the $\mathrm{BD}$. The following equation was used:

$$
\mathrm{x}=\left[\mathrm{D}_{\text {Diet }}-\left(\mathrm{D}_{\mathrm{BD}} a\right)\right] /(1-a)
$$

where $\mathrm{D}_{\text {Diet }}$ is the digestibility of $\mathrm{P}(\%)$ determined in the experimental diet, $\mathrm{D}_{\mathrm{BD}}$ is the digestibility of $\mathrm{P}(\%)$ in the basal diet and $a$ is the proportion of total $\mathrm{P}$ in the experimental diet supplied by the basal diet.

For data from experiments 2 and 3, the average digestibility determined for $\mathrm{P}$ from the BD in experiment 1 was used, as the basal diet was the same for all three experiments. After ANOVA procedures, Student-Newman-Keuls test was applied to evaluate differences in digestibilities determined between different ingredients within one grain.

The level of significance chosen was $\mathrm{P} \leq 0.05$.

\section{RESULTS}

In Table 3, the intake and excretion of $\mathrm{P}$ is shown for all diets. Mean $\mathrm{P}$ intake was only $\sim 0.4 \mathrm{~g} / \mathrm{d}$ when the basal diet was fed and ranged between 1.12 and 1.58 $\mathrm{g} / \mathrm{d}$ when test diets were fed. Mean urinary P excretion never exceeded $16 \mathrm{mg} / \mathrm{d}$.

The digestibilities of $\mathrm{P}$, calculated by difference for ingredients under test, are shown in Table 4, together with respective concentration of total P, proportion of phytate $\mathrm{P}$ in total $\mathrm{P}$ and activity of intrinsic phytase. Fertilization had no influence on the $\mathrm{P}$ digestibility in rye, wheat and barley. The results for the different varieties of wheat suggest an effect on digestibility of phosphorus, variety "Contra" showed a significantly lower digestibility of $\mathrm{P}$ than the other varieties. Mean digestibility of $\mathrm{P}$ in rye, field bean and barley was 70,36 and $46 \%$, respectively. Phosphorus digestibility in 12 batches of wheat ranged from 43 to $59 \%$, with a mean of $56 \%$. 
TABLE 3

Intake and excretion of phosphorus by pigs. Results given are means $\pm \mathrm{SD}, \mathrm{n}=4$

\begin{tabular}{lccc}
\hline Diet & Intake, g/d & Faeces, g/d & Urine, $\mathrm{mg} / \mathrm{d}$ \\
\hline BD & $0.44 \pm 0.11$ & $0.16 \pm 0.05$ & $6 \pm 3$ \\
BD + spring rye P+ D+ & $1.17 \pm 0.34$ & $0.35 \pm 0.11$ & $5 \pm 2$ \\
BD + spring rye P+ D- & $1.12 \pm 0.27$ & $0.35 \pm 0.08$ & $6 \pm 1$ \\
BD + spring rye P- D+ & $1.16 \pm 0.29$ & $0.39 \pm 0.10$ & $6 \pm 2$ \\
& & & \\
BD + spring wheat P+ D+ & $1.26 \pm 0.31$ & $0.51 \pm 0.13$ & $4 \pm 1$ \\
BD + spring wheat P+ D- & $1.20 \pm 0.25$ & $0.49 \pm 0.04$ & $4 \pm 1$ \\
BD + spring wheat P- D+ & $1.25 \pm 0.29$ & $0.53 \pm 0.13$ & $5 \pm 1$ \\
BD + spring wheat P- D- & $1.13 \pm 0.26$ & $0.47 \pm 0.11$ & $4 \pm 1$ \\
& & & \\
BD + winter wheat P0 N180 & $1.36 \pm 0.28$ & $0.55 \pm 0.12$ & $8 \pm 1$ \\
BD + winter wheat P44 N180 & $1.25 \pm 0.30$ & $0.53 \pm 0.11$ & $7 \pm 1$ \\
BD + winter wheat P0 N90 & $1.27 \pm 0.28$ & $0.52 \pm 0.10$ & $7 \pm 2$ \\
BD + winter wheat P44 N90 & $1.24 \pm 0.26$ & $0.53 \pm 0.08$ & $7 \pm 2$ \\
& & & \\
BD + winter barley P0 N150 & $1.50 \pm 0.36$ & $0.77 \pm 0.17$ & $9 \pm 2$ \\
BD + winter barley P44 N150 & $1.56 \pm 0.32$ & $0.80 \pm 0.11$ & $10 \pm 4$ \\
BD + winter barley P0 N75 & $1.55 \pm 0.34$ & $0.85 \pm 0.12$ & $10 \pm 4$ \\
BD + winter barley P44 N90 & $1.48 \pm 0.43$ & $0.80 \pm 0.18$ & $8 \pm 2$ \\
BD + field bean "Condor" & $1.58 \pm 0.37$ & $0.91 \pm 0.20$ & $6 \pm 2$ \\
BD + field bean "Scirocco" & $1.47 \pm 0.34$ & $0.85 \pm 0.20$ & $7 \pm 2$ \\
BD + winter barley "Hanna" & $1.50 \pm 0.35$ & $0.80 \pm 0.24$ & $6 \pm 3$ \\
BD + winter barley "Sarah" & $1.46 \pm 0.34$ & $0.68 \pm 0.15$ & $6 \pm 1$ \\
& & & \\
BD + winter wheat "Contra" & $1.12 \pm 0.26$ & $0.65 \pm 0.14$ & $4 \pm 2$ \\
BD + winter wheat "Flair" & $1.41 \pm 0.33$ & $0.59 \pm 0.12$ & $5 \pm 1$ \\
BD + winter wheat "Ritmo" & $1.38 \pm 0.41$ & $0.63 \pm 0.18$ & $5 \pm 1$ \\
BD + winter wheat "Tilburi" & $1.51 \pm 0.46$ & $0.67 \pm 0.15$ & $6 \pm 1$ \\
\hline
\end{tabular}

${ }^{1}$ long-term fertilizer trial; fertilization with $\mathrm{P}$ : with $(\mathrm{P}+)$ or without $(\mathrm{P}-)$; fertilization with animal dung: with (D+) or without (D-)

2 fertilization with P (44 kg P/ha; P44) or without P (P0); fertilization with $\mathrm{N}$ at different levels: 180 or $90 \mathrm{~kg} \mathrm{~N} / \mathrm{ha} \mathrm{(N180} \mathrm{or} \mathrm{N90),} 150$ or $75 \mathrm{~kg} \mathrm{~N} / \mathrm{ha} \mathrm{(N150} \mathrm{or} \mathrm{N75)}$ 
TABLE 4

Concentration of total $\mathrm{P}$, proportion of phytate $\mathrm{P}$ to total $\mathrm{P}$, activity of intrinsic phytase and digestibility of $\mathrm{P}$ in ingredients tested

\begin{tabular}{|c|c|c|c|c|c|c|}
\hline Grain & Variety & Fertilization & $\begin{array}{l}\text { Total-P } \\
\text { g/kg DM }\end{array}$ & $\begin{array}{l}\text { Phytate } \mathrm{P} \\
\% \text { of total } \mathrm{P}\end{array}$ & $\begin{array}{c}\text { Phytase } \\
\text { activity } \\
\mathrm{U} / \mathrm{kg}\end{array}$ & $\begin{array}{c}\text { Digestibility of } \mathrm{P}, \% \\
\text { mean } \pm \mathrm{SD}\end{array}$ \\
\hline $\begin{array}{l}\text { Spring } \\
\text { rye }\end{array}$ & Petka & $\begin{array}{l}\mathrm{P}+\mathrm{D}+{ }^{1} \\
\mathrm{P}+\mathrm{D}- \\
\mathrm{P}-\mathrm{D}+\end{array}$ & $\begin{array}{l}4.24 \\
4.09 \\
4.30\end{array}$ & $\begin{array}{l}71 \\
73 \\
70\end{array}$ & $\begin{array}{l}4030 \\
4440 \\
3890\end{array}$ & $\begin{array}{c}73 \pm 7 \\
71 \pm 10 \\
68 \pm 7\end{array}$ \\
\hline $\begin{array}{l}\text { Spring } \\
\text { wheat }\end{array}$ & Cadenza & $\begin{array}{l}\mathrm{P}+\mathrm{D}+ \\
\mathrm{P}+\mathrm{D}- \\
\mathrm{P}-\mathrm{D}+ \\
\mathrm{P}-\mathrm{D}-\end{array}$ & $\begin{array}{l}3.60 \\
3.43 \\
3.59 \\
3.40\end{array}$ & $\begin{array}{l}72 \\
76 \\
72 \\
74\end{array}$ & $\begin{array}{l}1300 \\
1140 \\
1270 \\
1180\end{array}$ & $\begin{array}{l}59 \pm 6 \\
58 \pm 5 \\
57 \pm 6 \\
57 \pm 8\end{array}$ \\
\hline $\begin{array}{l}\text { Winter } \\
\text { wheat }\end{array}$ & Charger & $\begin{array}{l}\text { P0 N180 } 2 \\
\text { P44 N180 } \\
\text { P0 N90 } \\
\text { P44 N90 }\end{array}$ & $\begin{array}{l}3.31 \\
3.31 \\
3.02 \\
2.90\end{array}$ & $\begin{array}{l}63 \\
68 \\
60 \\
63\end{array}$ & $\begin{array}{l}1010 \\
1100 \\
1080 \\
1130\end{array}$ & $\begin{array}{l}59 \pm 3 \\
56 \pm 7 \\
59 \pm 5 \\
57 \pm 3\end{array}$ \\
\hline $\begin{array}{l}\text { Winter } \\
\text { barley }\end{array}$ & Theresa & $\begin{array}{l}\text { P0 N150 } \\
\text { P44 N150 } \\
\text { P0 N75 } \\
\text { P44 N75 }\end{array}$ & $\begin{array}{l}3.91 \\
3.99 \\
3.98 \\
3.95\end{array}$ & $\begin{array}{l}83 \\
83 \\
85 \\
85\end{array}$ & $\begin{array}{l}370 \\
380 \\
300 \\
290\end{array}$ & $\begin{array}{l}47 \pm 3 \\
46 \pm 4 \\
42 \pm 9 \\
43 \pm 7\end{array}$ \\
\hline $\begin{array}{l}\text { Field } \\
\text { bean }\end{array}$ & $\begin{array}{l}\text { Condor } \\
\text { Scirocco }\end{array}$ & $\begin{array}{l}-3 \\
-\end{array}$ & $\begin{array}{l}6.21 \\
5.59\end{array}$ & $\begin{array}{l}71 \\
70\end{array}$ & $\begin{array}{c}<70 \\
70\end{array}$ & $\begin{array}{l}36 \pm 7 \\
36 \pm 6\end{array}$ \\
\hline $\begin{array}{l}\text { Winter } \\
\text { barley }\end{array}$ & $\begin{array}{l}\text { Hanna } \\
\text { Sarah }\end{array}$ & - & $\begin{array}{l}4.00 \\
3.99\end{array}$ & $\begin{array}{l}63 \\
55\end{array}$ & $\begin{array}{l}440 \\
820\end{array}$ & $\begin{array}{l}44 \pm 9 \\
52 \pm 3\end{array}$ \\
\hline $\begin{array}{l}\text { Winter } \\
\text { wheat }\end{array}$ & $\begin{array}{l}\text { Contra } \\
\text { Flair } \\
\text { Ritmo } \\
\text { Tilburi }\end{array}$ & $\begin{array}{l}- \\
- \\
- \\
-\end{array}$ & $\begin{array}{l}3.85 \\
3.53 \\
3.69 \\
4.05\end{array}$ & $\begin{array}{l}78 \\
79 \\
70 \\
84\end{array}$ & $\begin{array}{c}890 \\
890 \\
1130 \\
860\end{array}$ & $\begin{array}{l}43 \pm 5 \\
58 \pm 3 \\
53 \pm 3 \\
54 \pm 7\end{array}$ \\
\hline
\end{tabular}

${ }^{1}$ long-term fertilizer trial; fertilization with $\mathrm{P}$ : with $(\mathrm{P}+)$ or without $(\mathrm{P}-)$; fertilization with animal dung: with (D+) or without (D-)

${ }^{2}$ fertilization with P (44 kg P/ha; P44) or without P (P0); fertilization with $\mathrm{N}$ at different levels: 180 or $90 \mathrm{~kg} \mathrm{~N} / \mathrm{ha} \mathrm{(N180} \mathrm{or} \mathrm{N90),} 150$ or $75 \mathrm{~kg} \mathrm{~N} / \mathrm{ha}(\mathrm{N} 150$ or N75)

${ }^{3}$ unknown level of fertilization 


\section{DISCUSSION}

Mean urinary $\mathrm{P}$ excretion of pigs in these experiments was extremely low and ranged between 3 to $16 \mathrm{mg} / \mathrm{d}$ depending on the diet. This is a strong indication, that regulatory P excretion is minimised (Rodehutscord et al., 1998) and, therefore, calculated digestibilities here are suitable for characterising availability of $\mathrm{P}$ in the ingredients under test. In contrast to what has been recommended by GfE (1994) we determined the digestibility with piglets that initially weighed less than $30 \mathrm{~kg}$. It has been shown in the meantime, however, that digestibility of P from plant sources is not different between piglets and growing finishing pigs if determined at a sufficiently low level of P supply (Rodehutscord et al., 1999).

The batches of grain in experiment 1 came from a long-term fertilizer trial, i.e. fertilization remained constant for many years. It can be concluded, that the plot of land that received no fertilization with P (and even no animal dung) was very poor in phosphorus, and so represents an extreme kind of fertilization. If there is any influence of fertilization with $\mathrm{P}$, the batch of grain coming from this soil should indicate it. As there was neither a difference in phytate $\mathrm{P}$ and phytase nor in digestibility of $\mathrm{P}$ between these batches of spring rye and spring wheat, it can be concluded, that there is no influence of fertilization with $\mathrm{P}$ on digestibility of P. Also in winter barley and winter wheat there was no difference in phytate $\mathrm{P}$, phytase activity and digestibility of $\mathrm{P}$ between the batches, receiving different fertilization with P and/or N. Barrier-Guillot et al. (1996b) tested 56 batches of wheat on phytase activity and phytate $\mathrm{P}$. Factors on test were $\mathrm{N}$ and/or P fertilization, variety and date of harvest. Only the variety of wheat appeared as a significant factor determining phytase activity. None of the factors studied significantly affected phytate $\mathrm{P}$ content of the wheat. Four batches with different $\mathrm{P}$ fertilization where tested with pigs by Barrier-Guillot et al. (1996a) with no difference in P digestibility, which confirms our results. Düngelhoef and Rodehutscord (1995) reviewed effects of phytases on the digestibility of phosphorus in pigs. As part of the phosphorus of plant origin is bound as phytate $\mathrm{P}$, which is poorly available to the pig, the portion of phytate-bound $\mathrm{P}$, as well as the activity of intrinsic phytase, may affect the $\mathrm{P}$ digestibility. For estimation of $\mathrm{P}$ digestibility, regressions from analytical variables like phytase activity and phytate P content would be useful to save trials with animals. Only limited information on phosphorus digestibility (according to the method of GfE (1994)) is reported in the literature. Düngelhoef et al. (1994) tested triticale and wheat for P digestibility (52 and 62\%). Rodehutscord et al. (1996) studied digestibility of phosphorus in barley (45\%) and four varieties of wheat $(61-74 \%)$. Data on digestibility of $\mathrm{P}(\%)$ in barley $(38 / 57)$, triticale $(55 / 66)$, wheat (45/63) and field bean (21/40) were published by Berk and Schulz (1993) and Steinbeck (2000). Our data together with data from the literature shows no clear relationship between phytase activity (Figure 1) and phytate P (Figure 2) on 


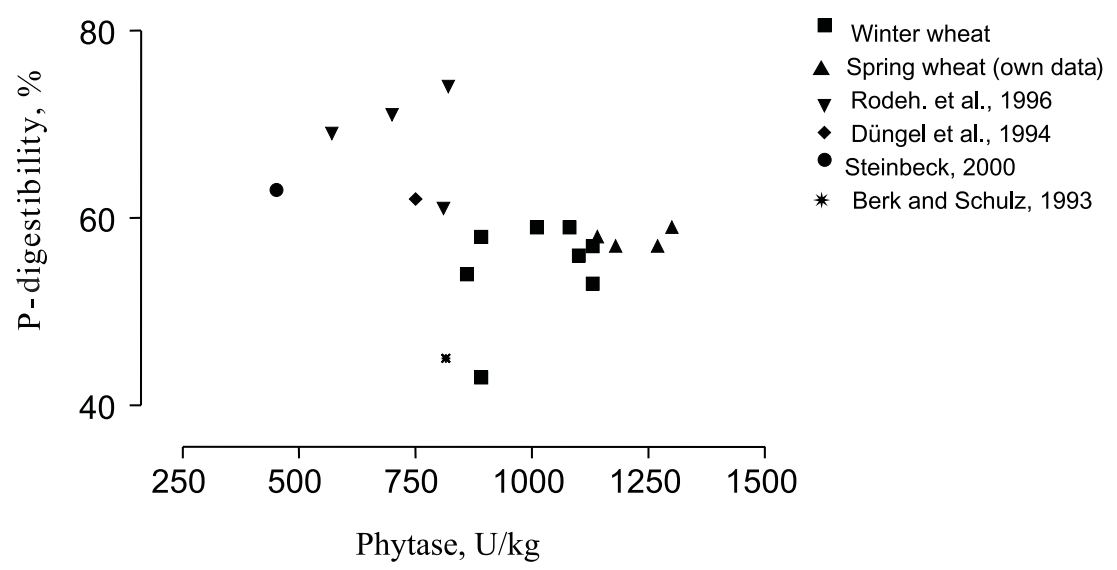

Figure 1 . Phytase activity and digestibility of $\mathrm{P}$ in wheat

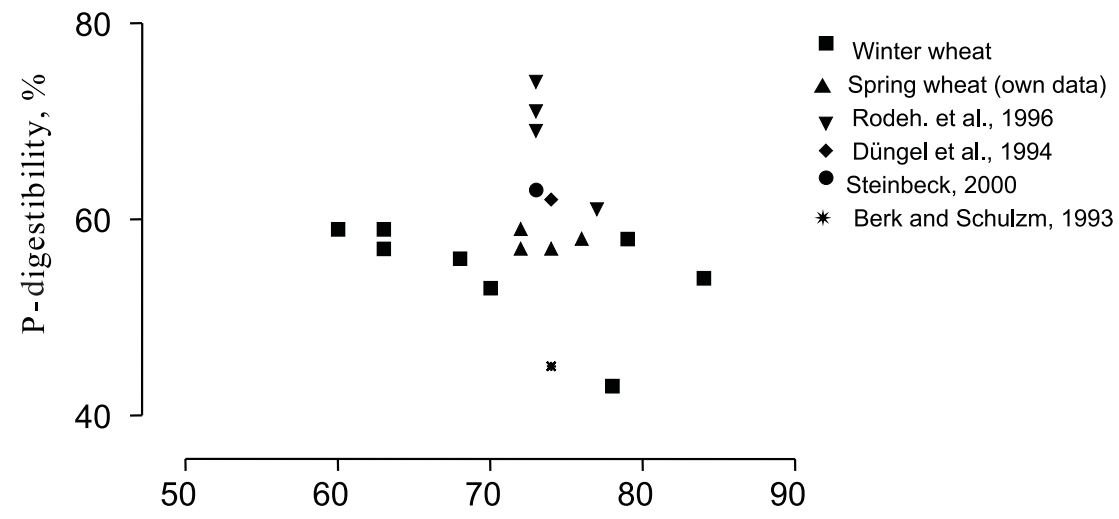

Phytate $\mathrm{P}, \%$ of total $\mathrm{P}$

Figure 2. Phytate $\mathrm{P}$ and digestibility of $\mathrm{P}$ in wheat

the one hand and digestibility of $\mathrm{P}$ on the other hand for 19 different batches of wheat. Estimated slopes of regression equations were not significantly different from zero. An estimation of $\mathrm{P}$ digestibility based on phytase or phytate $\mathrm{P}$ alone is not practicable.

This is in contrast to findings with broiler chickens, where a correlation was determined between the intrinsic phytase activity and $\mathrm{P}$ utilization for wheat (Oloffs et al., 2000). In barley only very little influence of phytase activity (Figure 3) and phytate $\mathrm{P}$ (Figure 4) on digestibility of $\mathrm{P}$ was found, mean digestibility of $\mathrm{P}$ in 9 batches of barley was $46 \%$. But even here slopes of regression equations were not significantly different from zero. Over all types of grain digestibility of $\mathrm{P}$ is 


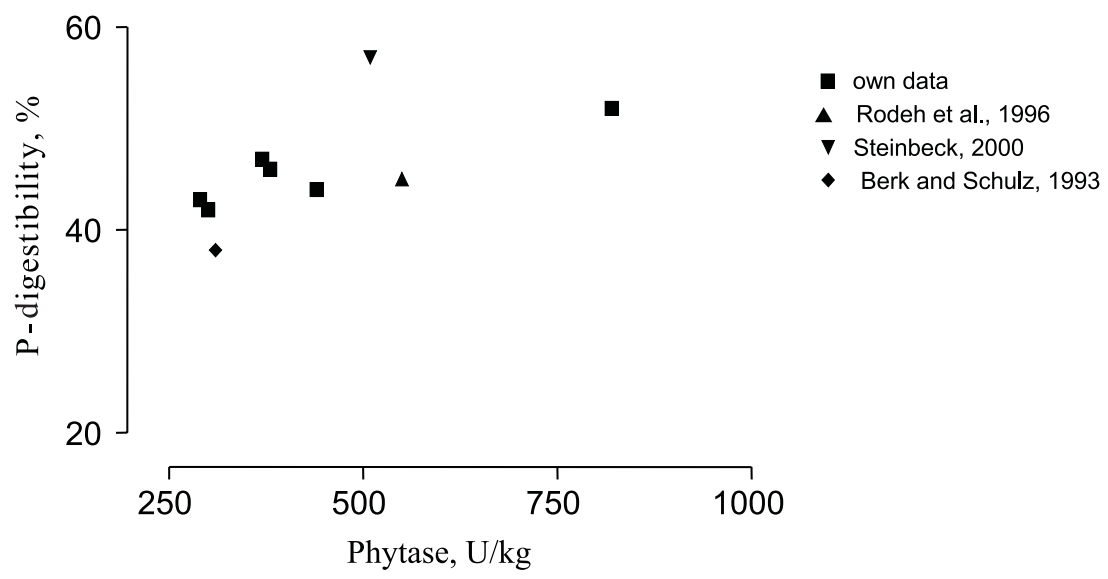

Figure 3. Phytase activity and digestibility of $\mathrm{P}$ in barley

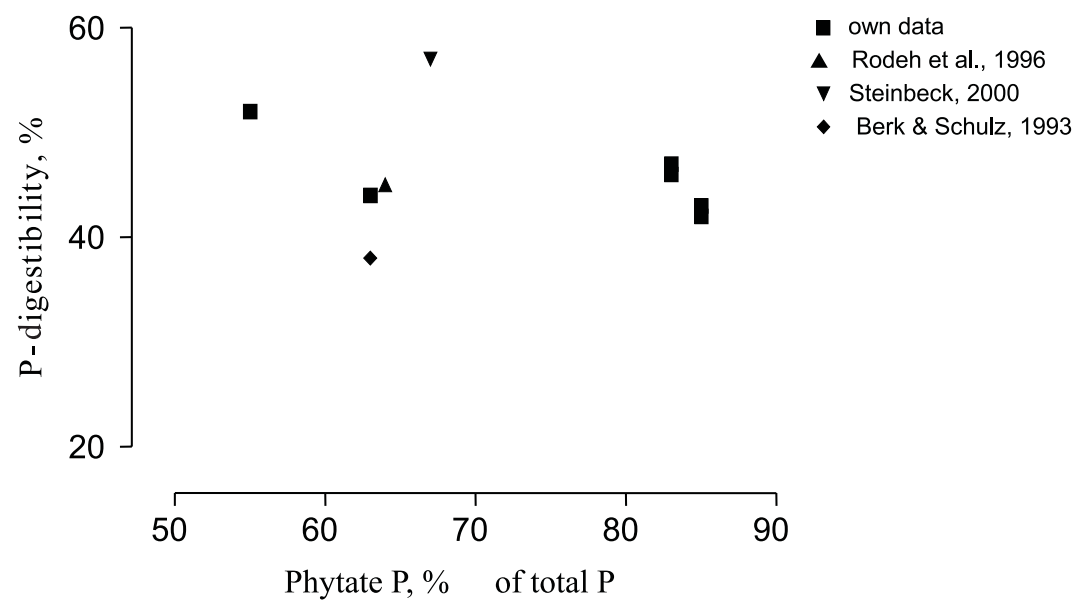

Figure 4. Phytate $\mathrm{P}$ and digestibility of $\mathrm{P}$ in barley

correlated with phytase activity $\left(\mathrm{r}^{2}=0.36\right.$; all data mentioned above), but as described before, within one grain (barley and wheat) no significant correlations could be found. For practical use, digestibility of P for feedstuffs should be classified by assuming different values for different types of grain.

Within the recommendations on digestible phosphorus of the Society of Nutrition Physiology (GfE, 1997) a table on digestibility of $\mathrm{P}$ in feedstuffs was published. Values for digestibility of $\mathrm{P}$ in barley (45\%) and field bean (39\%), each derived only from one trial, can be confirmed by our study on six batches of barley and two batches of field bean. From the results of 19 different batches of wheat presented herein, the currently suggested value for wheat (68\%) should be adjusted to $60 \%$. 


\section{REFERENCES}

Barrier-Guillot B., Casado P., Maupetit P., Jondreville C., Gatel F., 1996a. Wheat phosphorus availability: 2-In vivo study in broilers and pigs; relationship with endogenous phytasic activity and phytic phosphorus content in wheat. J. Sci. Food Agr. 70, 69-74

Barrier-Guillot B., Casado P., Maupetit P., Jondreville C., Gatel F., Larbier M., 1996b. Wheat phosphorus availability: 1-In vitro study; factors affecting endogenous phytasic acitvity and phytic phosphorus content. J. Sci. Food Agr. 70, 62-68

Berk A., Schulz E., 1993. Die Verdaulichkeit des Phosphors aus unterschiedlichen Futtermitteln beim Schwein während der Mast. VDLUFA-Kongreßband, pp. 309-312

Düngelhoef M., Rodehutscord M., 1995. Wirkung von Phytasen auf die Verdaulichkeit des Phosphors beim Schwein. Übers. Tierernähr. 23, 133-157

Düngelhoef M., Rodehutscord M., Spiekers H., Pfeffer E., 1994. Effects of supplemental microbial phytase on availability of phosphorus contained in maize, wheat and triticale to pigs. Anim. Feed Sci. Tech. 49, 1-10

Eeckhout W., De Paepe M., 1994. Total phosphorus, phytate-phosphorus and phytase activity in plant feedstuffs. Anim. Feed Sci. Tech. 47, 19-29

Engelen A.J., van der Heeft F.C., Randsdorp P.H.G., Smit E.L.C., 1994. Simple and rapid determination of phytase activity. J. AOAC Intern. 77, 760-764

GfE, 1994. Mitteilungen des Ausschusses für Bedarfsnormen der Gesellschaft für Ernährungsphysiologie: Die Bestimmung des verdaulichen Phosphors beim Schwein. Proc. Soc. Nutr. Physiol. 2, 113-119

GfE, 1997. Mitteilungen des Ausschusses für Bedarfsnormen der Gesellschaft für Ernährungsphysiologie: Überarbeitete Empfehlungen zur Versorgung von Schweinen mit Phosphor. Proc. Soc. Nutr. Physiol. 6, 193-200

Harland B.F., Oberleas D., 1986. Anion-exchange method for determination of phytate in foods: collaborative study. J. Assoc. Off. Anal. Chem. 69, 667-670

Naumann C., Bassler R., 1976. VDLUFA-Methodenbuch, Vol. III. Die chemische Untersuchung von Futtermitteln (Ergänzungen von 1983, 1988, 1993 und 1997 in loser Blattsammlung) VDLUFA-Verlag, Darmstadt

Oloffs K., Cossa J., Jeroch H., 2000. Die Bedeutung der nativen Phytaseaktivität im Weizen für die Phosphor-Verwertung bei Broilern und Legehennen. Proc. Soc. Nutr. Physiol. 9, 32 (Abstr.)

Rodehutscord M., Faust M., Lorenz H., 1996. Digestibility of phosphorus contained in soybean meal, barley, and different varieties of wheat, without and with supplemental phytase fed to pigs and additivity of digestibility in a wheat-soybean-meal diet. J. Anim. Physiol. Anim. Nutr. 75, 40-48

Rodehutscord M., Haverkamp R., Pfeffer E., 1998. Inevitable losses of phosphorus in pigs, estimated from balance data using diets deficient in phosphorus. Arch. Anim. Nutr. 51, 27-38

Rodehutscord M., Krause G., Pfeffer E., 1999. Effect of body weight on phosphorus digestibility and efficacy of a microbial phytase in young pigs. Arch. Anim. Nutr. 52, 139-153

Steinbeck A., 2000. Phosphorverdaulichkeit pflanzlicher Futtermittel beim Schwein und in-vitro Dialysierbarkeit von Mineralstoffen. Diss. Agr., Universität Giessen 


\section{STRESZCZENIE}

\section{Wpływ nawożenia odmiany pasz roślinnych na strawność fosforu u świń}

W trzech doświadczeniach oznaczono strawność fosforu pasz roślinnych dla świń. Zwierzęta o początkowej masie ciała $11 \mathrm{~kg}$, utrzymywanych w klatkach metabolicznych, karmiono dwa razy dziennie paszą w ilości przewyższającej około 2 do 2,5-krotnie zapotrzebowanie bytowe. Zwierzętom podawano pół-syntetyczną dietę podstawową o małej zawartości fosforu nie zawierającej aktywnej fitazy lub dietami doświadczalnymi z dodatkiem do diety podstawowej $60 \%$ jęczmienia lub pszenicy bądź 40\% bobiku lub żyta. Mieszanki zawierały nie więcej niż $2 \mathrm{~g}$ strawnego P/kg s.m. oraz od 5,0 do $6,0 \mathrm{~g} \mathrm{Ca} / \mathrm{kg}$ s.m. Kał i mocz zbierano ilościowo przez 7 dni po 7 dniowym okresie adaptacyjnym. Strawność fosforu doświadczalnych składników diety obliczano z różnicy jego strawności między dietą podstawową a doświadczalnymi. Strawność fosforu żyta trzech różnych odmian wynosiła średnio 70\%; fosforu bobiku z dwóch odmian -36\%; z 12 odmian pszenicy od 43 do $59 \%$ (średnio $46 \%$ ) oraz z 6 odmian jęczmienia od 42 do $52 \%$ ('średnio 46\%). Nie stwierdzono wpływu nawożenia azotowego i fosforowego na strawność fosforu pszenicy, żyta lub jęczmienia. Wpływ odmiany na strawność fosforu wykazano dla odmian jęczmienia i pszenicy. Zależność pomiędzy strawnością fosforu $\mathrm{z}$ jednej strony, a ilością fosforu fitynowego lub aktywnością dodanej fitazy z drugiej strony nie była jednoznaczna. 